\section{Hexokinase in human muscular dystrophy}

from a Correspondent

Controversy abounds at the moment about the pathogenesis of the severe X-linked form of muscular dystrophy, which is known as the Duchenne type and which usually results in the affected boys being unable to walk by the age of about 10 years and rarely surviving beyond the age of 20 . Within recent years McComas, Sica and Currie (Nature, 226, 1263; 1970) have suggested that the progressive degeneration of skeletal muscle which occurs in this condition may be the result of a primary defect in the motor neurones, whereas Hathaway, Engel and Zellweger (Archs Neurol., Chicago, 22, 365; 1970) have postulated a process of progressive ischaemia of muscle because of $a$. superficial similarity of the pathological changes in skeletal muscle in such cases to those produced by experimental muscle embolism in animals. These hypotheses have challenged the traditional view that this and other forms of genetically determined muscular dystrophy are likely to be due to a primary biochemical abnormality of the muscle cell itself, though it is certainly possible that a genetically determined biochemical defect could influence the function of both motor neurones and skeletal muscle.

Ellis, Strickland and Eccleston (Clin. Sci., 44, 321; 1973) have previously found that muscle obtained by biopsy from patients with Duchenne type muscular dystrophy is less able than is normal muscle to utilise glucose by the usual pathway of glycolysis. They found that in such tissue there was partial conversion of glucose to fructose instead of to glucose 6-phosphate under certain metabolic conditions. The

the trailing margins continued to subside as the newly created ocean floor coolcd progressively and hence became more dense. It remains to be seen whether this model can account in a satisfactory quantitative way for several thousand metres of subsidence since the early Cretaceous, apparently regardless of the age of opening.

Although the Atlantic margins offer interesting problems their solution seems relatively straightforward compared with those posed by substantially land-locked marine basins such as the Gulf of Mexico, the Black Sea and parts of the Mediterranean Sea. For the Black Sea Brinkmann (Am. Ass. Petrol. Geol. Mem., 20, 63; 1974) has conversion of glucose to glucose 6-phosphate is normally catalysed by hexokinase, an enzyme present in mammalian tissue in the form of several isoenzymes which differ in their $K_{\mathrm{m}}$ values for glucose.

Strickland and Ellis have now found certain abnormalities of hexokinase isoenzyme mobility when studied electrophoretically in muscle obtained from patients suffering from X-linked Duchenne type muscular dystrophy and the similar but more benign X-linked Becker variety (this issue of Nature, page 464). They find that tissue obtained from patients with these two diseases shows three, instead of the normal two, bands for hexokinase, two of which move relatively faster than do the bands of the normal isoenzyme II, and an additional slowermoving band close to isoenzyme I. Similar isoenzyme changes were found in liver, brain and sciatic nerve obtained at post-mortem from patients with Duchenne type muscular dystrophy. As the authors point out, this alteration in hexokinase isoenzyme II in a number of tissues obtained from patients with muscular dystrophy might account for a restricted flow of glucose through the hexokinase step in tissues where iosenzyme II is required. If such an abnormality were to prove to be of fundamental importance in the pathogenesis of muscular dystrophy, it could certainly account for abnormalities in the function of both neurones and muscle cells in this disease. Confirmation of this work and further studies of hexokinase isoenzyme behaviour in muscle and other tissues obtained from patients with X-linked muscular dystrophy will be awaited with interest.

outlined the abundant palaeogeographical evidence that it was the site of a terrestrial sediment source for much of the Palaeozoic and early Mesozoic. Yet seismic surveys reveal that the crust underlying the Black Sea has suboceanic thicknesses. Probably the most plausible interpretation of the existing data is that thick Upper Cretaceous and Tertiary sediments rest on a much attenuated continental crust. The obvious question arises, what has caused the thinning? Unlike the case of the Atlantic margins it cannot readily be related to a generally accepted plate tectonic model.

The case of the Mediterranean basins is perhaps even more intriguing, since we have two quite different interpretations of their origin, one invoking lateral, the other vertical movements. Western Mediterranean basins such as the Balearic Basin and Tyrrhenian Sea have a crust which is at least suboceanic if not fully oceanic in character, though no magnetic anomalies indicative of seafloor spreading have been dicovered. Palaeomagnetic evidence for the anticlockwise rotation of Corsica, Sardinia and Italy has been held to confirm Carey's proposal that the western Mediterranean basins are sphenochasms, that is, wedge-shaped sectors of ocean floor created by the movement apart of slabs of continent. Hsü and others have adopted this model to account for the existence in the deep basins of substantial deposits of late Miocene $\mathrm{NaCl}$ and $\mathrm{CaSO}_{4}$ salts which bear the characteristics of continental salina and sabhka deposits. To explain this apparent paradox a boldly imaginative hypothesis has been put forward (Hsü, Nature, 233, 44; 1971; Hsü et al., Init, Rep. Deep Sea Drilling Project, vol. 13, 1203; 1972). After Africa closed on Europe during the early Tertiary and sphenochasms opened up in the intermediate zone, a stage was reached when a series of land-locked basins several thousand metres deep were created in the Miocene. Because the climate was warm and arid the Mediterranean remained substantially dry, except for shallow brine pools in the deep basins, where salts began to precipitate. River canyons were cut down as much as $2,000 \mathrm{~m}$ through the surrounding continental margins to a base level well below ocean level. Subsequently, in the Pliocene, the Straits of Gibraltar were opened up and sea water flooded in from the Atlantic, rapidly drowning the basins and canyons and allowing normal deep sea muds to be deposited. As a defence against an admittedly extravagant, though attractive, hypothesis, Hsü has quoted Sherlock Holmes: "When you have excluded the impossible, whatever remains, however improbable, must be the truth."

But can the 'impossible' be excluded? Let us consider some other facts. There is an old idea that the Tyrrhenian Sea, like the Black Sea, is the site of a subsided landmass. This idea has received impressive support from the dredging of continental metamorphic rocks from the margin of a tilted fault block in the centre of the sea, implying late Tertiary subsidence in excess of 3,000 m (Heezen et al., Nature, 229, 327; 1971). The occurrence of a parallel series of ridges and troughs suggests a series of fault blocks like the Great Basin regime of the western United States and implies considerable thinning of continental crust by tension. More recently, combined geophysical 